\title{
Measuring Managers' and Professionals' Perceptions and Attitudes towards Information and Communication Technology Projects in Japan
}

\author{
Michiko Miyamoto \\ Department of Management Science and Engineering, Faculty of Systems Science and Technology, Akita Prefectural University, Japan
}

Copyright $(2017$ by authors, all rights reserved. Authors agree that this article remains permanently open access under the terms of the Creative Commons Attribution License 4.0 International License

\begin{abstract}
This study examines attitudes and feelings of managers and professionals of Information and Communication Technology (ICT) project management teams in order to complete the assignment. Especially, relationships between factors, such as communication, internal work motivation, general satisfaction, internal work motivation and job involvement for both groups are analyzed by using a framework and empirical analyses for the survey data from 1,678 managers and professionals working in a collaborative environment for Japanese software houses. The results of the research model using Structural Equation Modeling (SEM) show that internal work motivation, and job involvement are highly related to their satisfaction for both groups. However, each group feels differently on a relationship between communication and internal work motivation. The manager regards communications are highly related to internal motivation, while professionals do not feel the same way.
\end{abstract}

Keywords Project Management, Managers, Professionals, Structural Equation Modeling

\section{Introduction}

Productive and efficient project management teams are crucial to the success for many firms in the Information and Communication Technology (ICT) industry. Project management is a process involving full lifecycle of a project, from project launch to its completion [1] [2] [3] [4] [5] [6] [7] [8]. A project, which is completed on time and on budget, is regarded as successful. The Standish Group's 2015 CHAOS Reports, which studied 50,000 projects around the world, enhanced a definition of success of projects by looking at some additional factors which were covered in previous surveys; i.e., on time, on budget with a satisfactory result [9]. People's behavior is one of the key factors that drive successful project management. Surveys in UK, Australia, and Canada reported their findings about the "real world" experiences of people active in project management [10]. Planning, execution and control of all resources, tasks and activities are necessary to complete a project. Project management is usually conducted by team effort.

Ideally, team members create value by combining their efforts and talents with other individuals of the same project team under sufficient leadership. Personal satisfactions of individuals with other members and motivation to sustain those relationships are important indications of integration within a group [11]; however, the heterogeneity is often found among such project management teams, as it is rarely found a project team made up by individuals from the same organization tenure. The project team, per se, is rather a mixture of individuals from different background as the organization customary hires outside consultants based on their area of expertise to cover a lack of in-house human resources; so that the organization can provide the best service to its user customers. Thus, every time a new project launches, more likely a new project management team is created. Each team member has to cope with uncertainly of the team itself while the team has to successfully complete its assignment on time and on budget. Those newly formed project management teams most likely do not have a set of appropriate role behaviors, norms nor values. How these project management teams operate efficiently and productively? What kinds of factors motivate team members, most of them are ICT professionals, to work efficiently and productively within such a project management team? This study examines determinants which motivates managers and professionals of project management teams in order to complete the assignment. Using 37 on-going projects with 737 respondents in the Japanese IT Industry, this study explores the relationships and the integration within the group, different individual motivations for managers and professionals, and analyzes the perceived performance of project management teams. 
This paper is divided into the following sections: In Section 2, I discuss related works and hypotheses. Section 3 describes data. Section 4 discusses estimates from the models. Section 5 contains conclusions.

\section{Related Works and Hypotheses}

As far as project management concerned, the problem and the solution lay in people and processes. Project management teams, which could develop better processes, organize teams more effectively and deal with problems faster, may complete the project successfully on time and on budget. While people and processes are keys for a successful project management, there is little research on people aspect of project management team. The affective outcomes for organization member to engage in for the organization to function effectively were suggested by Feldman [12].

1. General satisfaction: Overall measure of the employee's satisfaction with work [13].

2. Internal work motivation: Self-motivation to perform effectively on the job [13].

3. Job involvement: Commitment to and involvement in work [14].

The study on newly formed groups suggests there are four typical stages of group development; forming, storming, norming, and performing [15]. Groups respond not to the structure of the situation but to their own precedents, set early in their initial interactions, and newly formed groups' behaviors are most strongly determined by the norms that developed when they least knew what they should be doing [16]. Before performing as an effective project team, each team member from different background has to transform from team outsiders to participating and effective members [17]. Feldman [18] emphasized that norms can form by fiat, because of a critical event, due to primacy or due to group member's similar past experiences. The study on organizational socialization present three distinct views: the development of work skills and abilities; the acquisition of a set of appropriate role behaviors; and the adjustment to the work group's norms and values [12].

A life of the project team lasts as long as the project lasts; the shortest projects go on from three months to a couple of years, while the long projects last a decade or two.

The study of organizational demography and turnover [19] suggests that conflict is generated by differences in organizational goals, values and beliefs about the connections between actions and consequences at the group level. In a case of project management, each team's goal is clear, i.e., 'a completion of the project', however there are uncertainty over appropriate behavior as a leader or a team member.

According to Duncan [20] components comprising the organization are expressed according by internal and external environment; the internal environment includes components such as organizational personnel component, organizational functional and staff units component, and organizational level component; external environment which includes customer component, suppliers component, competitor component, socio-political component, and technological component. In the case of project management teams, both internal and external environments are already comprised. The growing importance of a project management team with high performance level presents difficult challenges for management. The studies in organizational demography suggested that the general concepts of demography could have substantial effects on organizational outcomes such as innovation, performance, and control [21], and it is the distribution of people within a group across variables such as age or tenure that influences behavior, rather than simpler descriptions of the same variables, such as the mean age of the group or the proportion of the group with a particular tenure [22].

There are some studies in the area of product development teams, and they suggest that the homogeneity of organization tenure and the mix of functional specialties are the two variables likely to be of particular importance [22]. In their study, the teams are made up by the mix of functional specialties; however, they come from the same organization, while typical project management teams are formed by the mix of functional professionals from different background.

According to Project Management Institute [23], communication is a core competency which connects project team members to a common set of strategies, goals and actions, and is the most crucial success factor. Highly effective project leaders are shaped not only by their technical knowledge and capabilities, but by how effectively they communicate with others at all levels [24].

Based on previous literature, the author would like to propose the research model to gain a better understanding of different attitudes or feelings by managers and professionals in ICT project teams for Japanese software houses as shown in Fig.1.

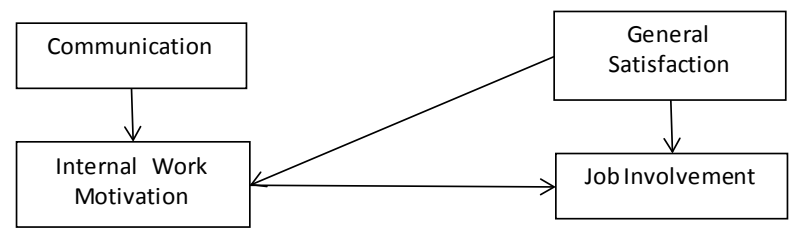

Figure 1. The Research Model

The author had formed four hypotheses based on this framework as follows;

H1: There is a significant, positive relationship between communication and internal work motivation.

$\mathrm{H} 2$ : There is a significant, positive relationship between general satisfaction and internal work motivation

H3: There is a significant, positive relationship between internal work motivation and job involvement.

H4: There is a significant, positive relationship between general satisfaction and job involvement. 
Table 1. Descriptive Statistics

\begin{tabular}{llrlr}
\hline Sex & $\cdot$ male & 1,276 & $\cdot$ female & 265 \\
\hline Age & $\cdot 25$ or below & 35 & $\cdot 26-30$ & 499 \\
& $\cdot 31-40$ & 656 & $\cdot$ over 41 & 53 \\
\hline Affiliation & $\cdot$ user & 676 & $\cdot$ employee & 500 \\
& $\cdot$ software house & 56 & $\cdot$ consultant & 33 \\
& $\cdot$ individual entrepreneurs & 13 & $\cdot$ others & 40 \\
\hline Role within the project & $\cdot$ manager & 521 & $\cdot$ professional & 1,081 \\
\hline Professional experiences & $\cdot$ less than 2years & 275 & $\cdot 3-5$ years & 428 \\
& $\cdot 6-10$ years & 416 & $\cdot$ over 11years & 563 \\
\hline Your work place & $\cdot$ disperse & 772 & $\cdot$ concentrate & 807 \\
& $\cdot$ others & 16 & \\
\hline Number of people at the work place & $\cdot$ less than 5 & 239 & $\cdot 6-20$ & 595 \\
& $\cdot 21-50$ & 388 & $\cdot 51-100$ & 196 \\
& $\cdot$ more than 101 & 278 & \\
\hline Management style of the project & $\cdot$ top down & 928 & $\cdot$ independent & 596 \\
\hline Length of your participation & $\cdot$ less than 1 month & 94 & $\cdot$ less than $3 \mathrm{mo}$ & 212 \\
in the project & $\cdot$ less than 6 mo & 200 & $\cdot$ less than $1 \mathrm{yr}$ & 325 \\
& $\cdot$ over 1yr & 804 & \\
\hline
\end{tabular}

\section{Data}

\subsection{Survey}

The raw survey data and the supplementary information on actual project management teams were collected by Enokida and Matsuadani [25]. Data were collected from individuals who participated in 37 project teams of software development companies in Japan. The questionnaires were sent each software company and they were distributed to appropriate project management teams from January to March, 2002. There are 737 questionnaires were returned for a $92 \%$ response rate.

Table 1 shows the descriptive statistics of data. Ages of project team members are varied from in twenties to fifties, and a mean age is thirties. Average respondents' profiles were regarded as highly educated with an average of 10 years or more of business experiences. There are 521 managers, while there are 1,081 professionals.

The list of variables obtained from the questionnaire survey is shown in Table 2. Table 3 contains the Pearson correlation coefficient between all pairs of sixteen variables with the two-tailed significance of these coefficients. All variables correlate fairly well and are statistically significant, and none of the correlation coefficients are particularly large; therefore, multicollinearity is not a problem for these data.

\section{Results}

Testing the efficacy of the structural equation model was conducted by AMOS 22, and the major results of analysis for leaders are shown in Fig. 2, and those for professionals are shown in figure 3 , respectively. The path diagram highlights the structural relationships.
In this diagram, the measured variables are enclosed in boxes, latent variables are circled, and arrows connecting two variables represent relations, and open arrows represent errors.

When SEM is used to verify a theoretical model, a better goodness of fit is required for SEM analysis ${ }^{11}$; the better the fit, the closer the model matrix and the sample matrix. By means of various goodness-of-fit indexes, including the comparative fit index (CFI) [26], the incremental fit index (IFI) [27], and the root mean squared error of approximation (RMSEA) [28] the estimated matrix can be evaluated against the observed sample covariance matrix to determine whether the hypothesized model is an acceptable representation of the data. In general, incremental fit indexes (i.e., CFI, IFI) above 0.90 signify good model fit. RMSEA values lower than 0.08 signify acceptable model fit, with values lower than 0.05 indicative of good model fit [28]. The research model is shown in Fig. 2; $\mathrm{CFI}=0.919$, $\mathrm{IFI}=0.920$, RMSEA $=0.053$ (see table 4). The Path Coefficient for both structural models suggested that the regression coefficient for all constructs show significance. Since all of the indexes satisfy the cut-off values, these results are regarded as acceptable.

A result of the research model for managers of software development houses' project management in Japan shows the following four findings;

H1: There is a significant, positive relationship between communication and internal work motivation.

$\mathrm{H} 2$ : There is a significant, positive relationship between general satisfaction and internal work motivation.

H3: There is a significant, positive relationship between internal work motivation and job involvement.

H4: There is a significant, highly positive relationship between general satisfaction and job involvement. 
Table 2. A List of Variables

\begin{tabular}{|l|ll|}
\hline \multirow{3}{*}{$\begin{array}{l}\text { Seneral } \\
\text { Satisfaction }\end{array}$} & q36 & Satisfied with workplace relationships of project \\
& q28 & Responsibility of the project given is appropriate. \\
& q13 & Projet managers have discretionary decision-making to meet requrements adequately. \\
\hline \multirow{3}{*}{$\begin{array}{l}\text { Job } \\
\text { involvement }\end{array}$} & q1 & Challeng worth works are given \\
& q38 & A sense of accomplishment for the day-to-day project work. \\
& q19 & A leader establishes clear project goals, roles and responsibilities. \\
\hline \multirow{5}{*}{ Communication } & Impossible, excessive, or unreasonable requests are not given. \\
\hline & q27 & It is possible to speak freely and make suggestions \\
& q25 & Informal communication with project members is good. \\
& q22 & Communication between teams of each of the project is a good. \\
\hline Internal work & q31 & It is possible to enhance your ability through the current project \\
motivation & q33 & Evaluated correctly and impartially. \\
& q34 & Results of the project have been reflected in the promotion and salary increases. \\
& q35 & Receive a salary commensurate with responsibilities. \\
\hline
\end{tabular}

Table 3. A Correlation Matrix

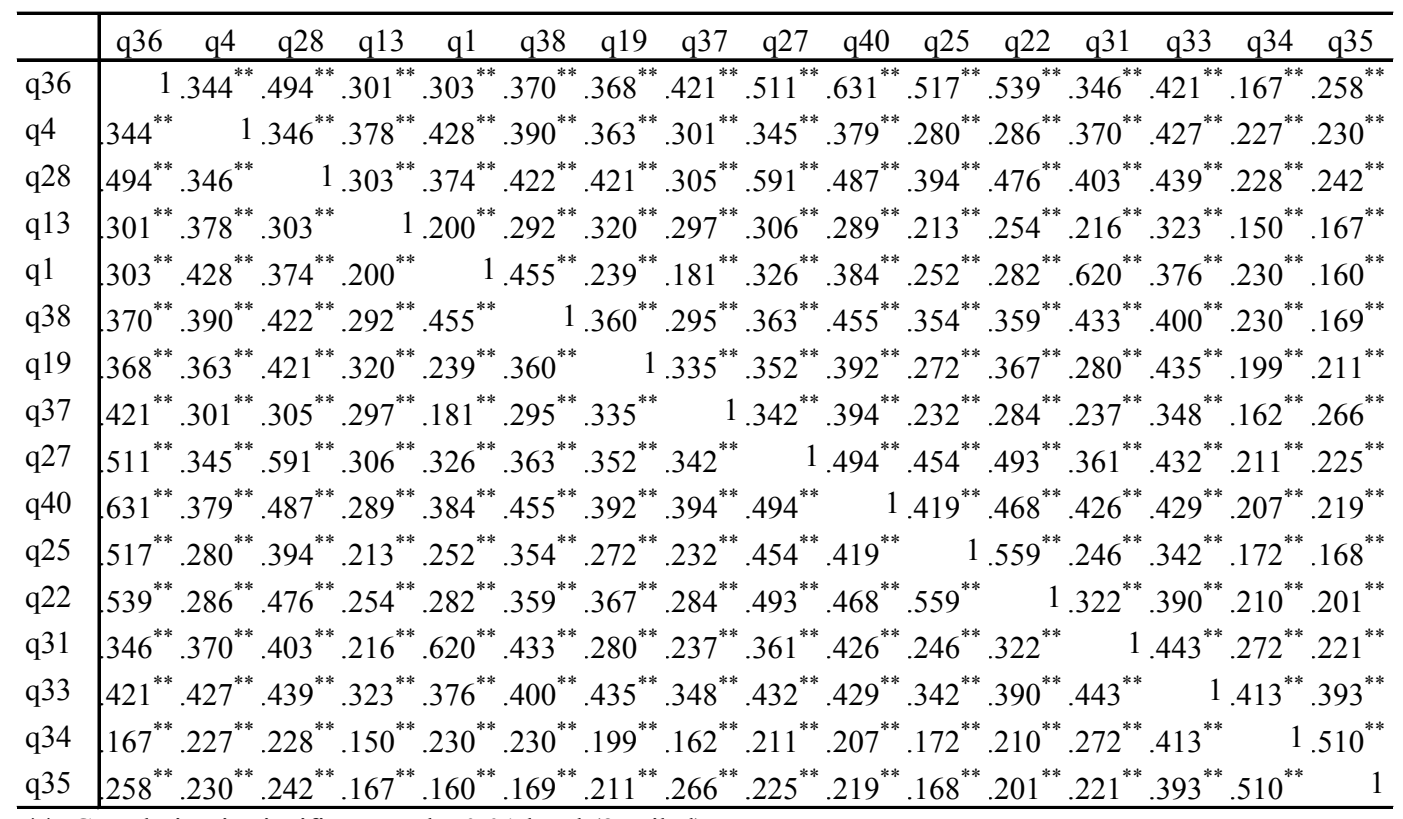

**. Correlation is significant at the 0.01 level (2-tailed).

Table 4. Reliability Test

\begin{tabular}{llc}
\hline FIT indices & Recommended level & Research Model \\
\hline CMIN/DF & $5.0[32] \sim 2.0[31]$ & 5.51 \\
CFI & $>0.90[26]$ & 0.919 \\
IFI & $>0.90[27]$ & 0.920 \\
RMSEA & $<0.08[28]$ & 0.053 \\
AIC & Smaller values suggest a good fitting [30] & 1204.804 \\
p-value & $>0.05$ & 0.000 \\
\hline
\end{tabular}




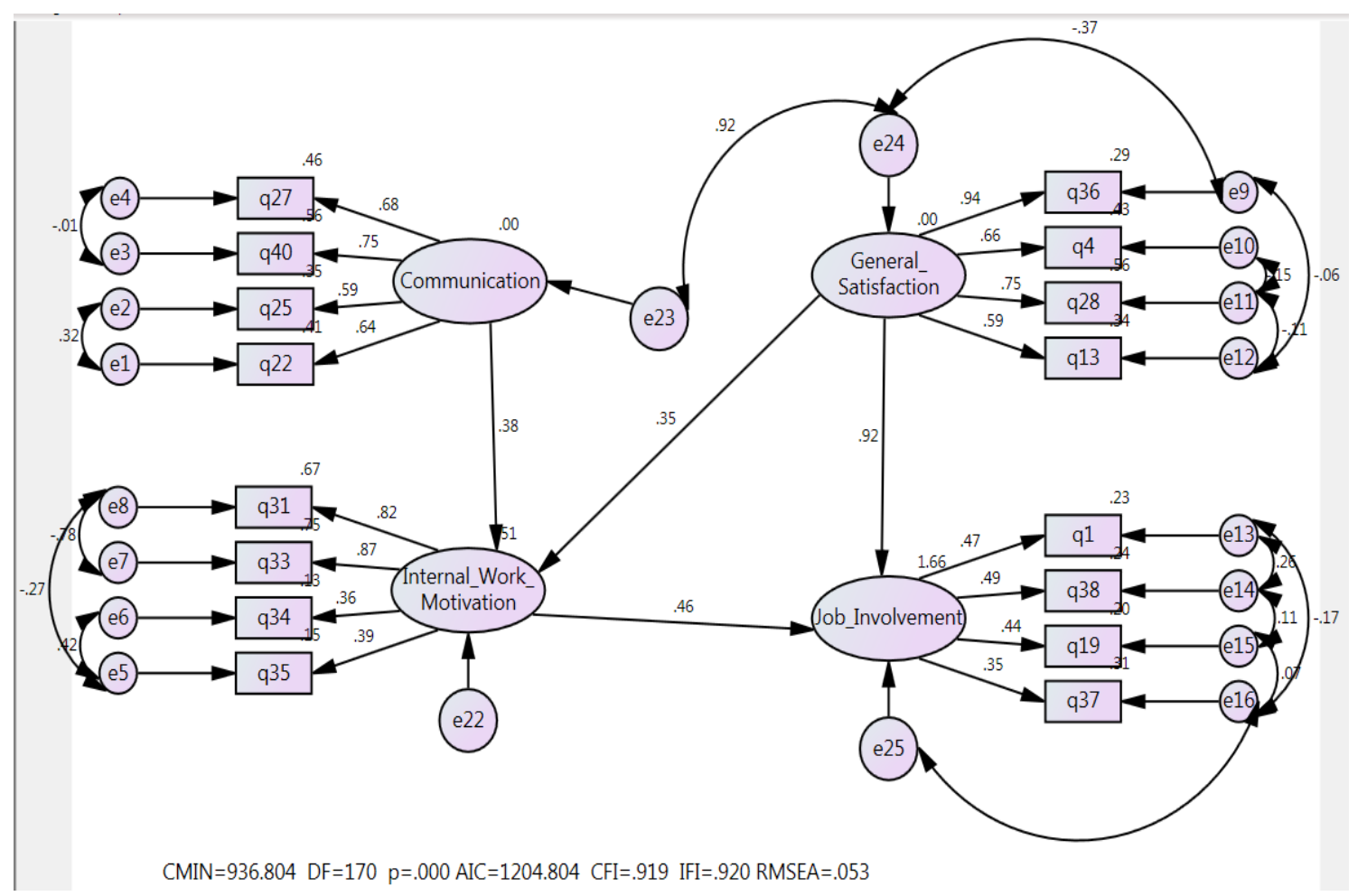

Figure 2. The Research Model for Managers

A result of the research model for professionals of software development houses' project management in Japan shows the following four findings;

H1: There is not a significant, positive and almost no relationship between communication and internal work motivation.

$\mathrm{H} 2$ : There is a significant, positive relationship between general satisfaction and internal work motivation

H3: There is a significant, positive relationship between internal work motivation and job involvement.

H4: There is a significant, highly positive relationship between general satisfaction and job involvement.

The results of both research models for managers and professionals suggest "general satisfaction" is closely related to "internal work motivation" and "job involvement." At the same time, "internal work motivation" is closely related to "job involvement" for both groups. However, there are different attitudes and feelings for a relationship between communication and internal work motivation. There is a significant, positive relationship between communication and internal work motivation for leaders, while those relationships for professionals are not related, nor statistically significant.

More specifically, professionals think internal work motivations, such as "It is possible to enhance your ability through the current project (q31)," "Evaluated correctly and impartially (q33)," "Results of the project have been reflected in the promotion and salary increases (q34)," and "Receive a salary commensurate with responsibilities (q35)" are positive but not related, nor significant with communication.

\section{Conclusions}

In this study, factors, which motivate managers and professionals for project management teams, are analyzed. For both groups, internal work motivation, and job involvement are highly related to their satisfaction. 
Table 5. The Path Coefficients of Research Model for Leaders

\begin{tabular}{|c|c|c|c|c|c|c|c|}
\hline construct & & & $\begin{array}{c}\text { Std. } \\
\text { weight } \\
\end{array}$ & $\begin{array}{l}\text { Unstd. } \\
\text { weight }\end{array}$ & S.E. & $\begin{array}{c}\text { C.R. } \\
\text { (t-value) }\end{array}$ & $P$ value \\
\hline Internal_Work__Motivation & $<---$ & General_Satisfaction & 0.352 & 0.151 & 0.056 & 2.712 & 0.007 \\
\hline Internal_Work_Motivation & $<---$ & Communication & 0.377 & 0.237 & 0.081 & 2.943 & 0.003 \\
\hline Job_Involvement & $<---$ & General_Satisfaction & 0.925 & 0.483 & 0.067 & 7.17 & $* * *$ \\
\hline Job_Involvement & $<---$ & Internal_Work__Motivation & 0.459 & 0.561 & 0.141 & 3.993 & $* * *$ \\
\hline $\mathrm{q} 22$ & $<---$ & Communication & 0.642 & 1 & & & \\
\hline $\mathrm{q} 25$ & $<---$ & Communication & 0.589 & 0.9 & 0.065 & 13.746 & $* * *$ \\
\hline $\mathrm{q} 40$ & $<---$ & Communication & 0.751 & 1.198 & 0.087 & 13.849 & $* * *$ \\
\hline q27 & $<---$ & Communication & 0.678 & 1.138 & 0.089 & 12.768 & $* * *$ \\
\hline $\mathrm{q} 35$ & $<---$ & Internal_Work__Motivation & 0.389 & 1 & & & \\
\hline q34 & $<---$ & Internal_Work__Motivation & 0.362 & 0.945 & 0.128 & 7.395 & $* * *$ \\
\hline q33 & $<---$ & Internal_Work__Motivation & 0.867 & 2.22 & 0.324 & 6.851 & $* * *$ \\
\hline $\mathrm{q} 31$ & $<---$ & Internal_Work__Motivation & 0.816 & 2.21 & 0.34 & 6.502 & $* * *$ \\
\hline q36 & $<---$ & General_Satisfaction & 0.937 & 1 & & & \\
\hline $\mathrm{q} 4$ & $<---$ & General__Satisfaction & 0.657 & 0.65 & 0.052 & 12.387 & $* * *$ \\
\hline q28 & $<---$ & General_Satisfaction & 0.75 & 0.813 & 0.058 & 13.972 & $* * *$ \\
\hline q13 & $<---$ & General_Satisfaction & 0.587 & 0.65 & 0.06 & 10.893 & $* * *$ \\
\hline q1 & $<---$ & Job_Involvement & 0.475 & 1 & & & \\
\hline $\mathrm{q} 38$ & $<---$ & Job_Involvement & 0.489 & 0.915 & 0.075 & 12.186 & $* * *$ \\
\hline q19 & $<---$ & Job_Involvement & 0.444 & 0.952 & 0.099 & 9.66 & $* * *$ \\
\hline $\mathrm{q} 37$ & $<---$ & Job_Involvement & 0.348 & 0.74 & 0.088 & 8.374 & $* * *$ \\
\hline
\end{tabular}

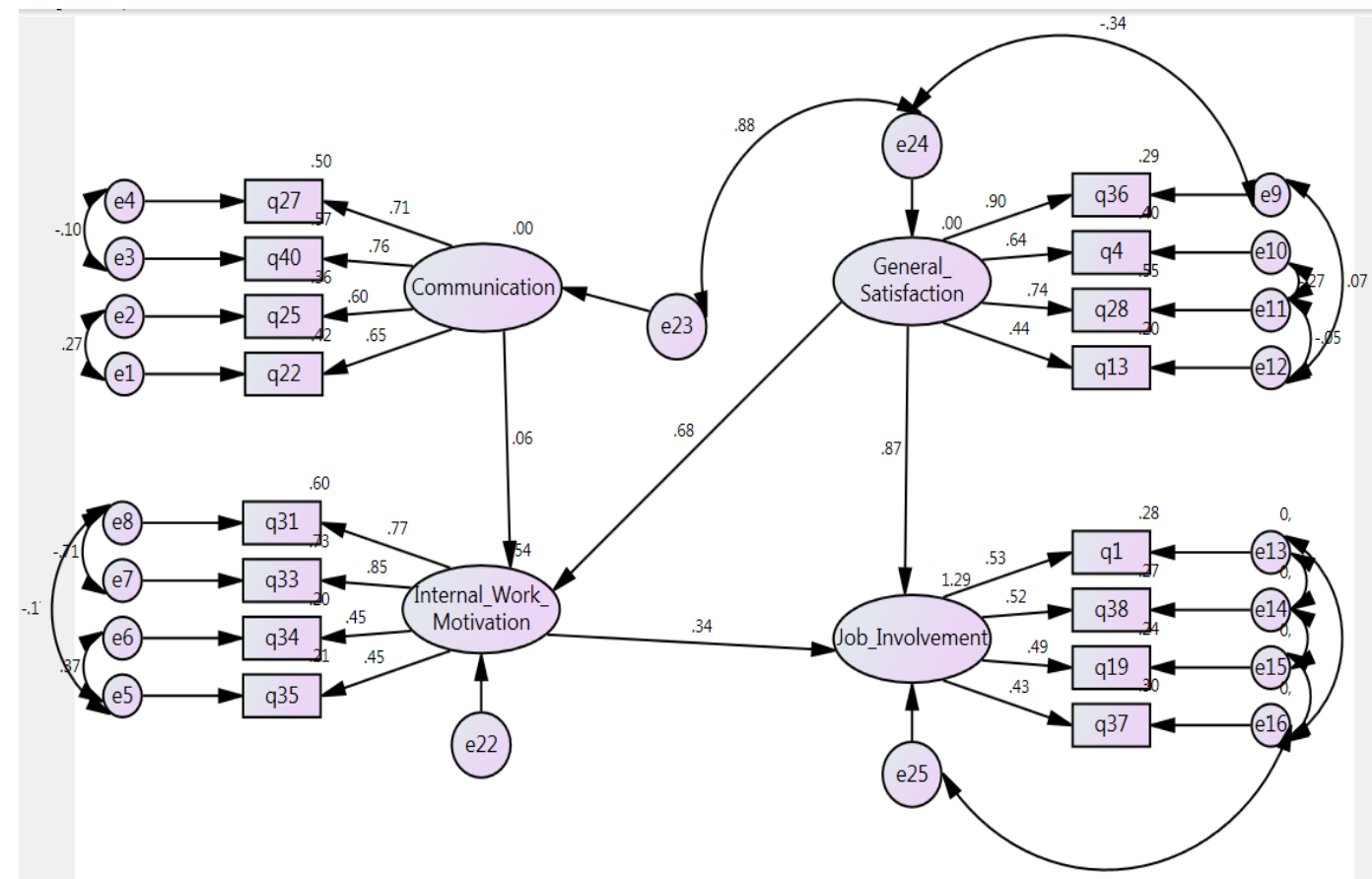

$\mathrm{CMIN}=936.804 \mathrm{DF}=170 \mathrm{p}=.000 \mathrm{AIC}=1204.804 \mathrm{FI}=.919$ IFI-1.920 RMSEA $=.053$

Figure 3. The Research Model for Professionals 
Table 6. The Path Coefficients of Research Model for Professionals

\begin{tabular}{|c|c|c|c|c|c|c|c|}
\hline construct & & & $\begin{array}{c}\text { Std. } \\
\text { weight }\end{array}$ & $\begin{array}{l}\text { Unstd. } \\
\text { weight }\end{array}$ & S.E. & $\begin{array}{c}\text { C.R. } \\
\text { (t-value) }\end{array}$ & $\mathrm{P}$ value \\
\hline Internal_Work__Motivation & $<---$ & General_Satisfaction & 0.678 & 0.349 & 0.057 & 6.132 & $* * *$ \\
\hline Internal_Work__Motivation & $<---$ & Communication & 0.06 & 0.042 & 0.062 & 0.675 & 0.499 \\
\hline Job_Involvement & $<---$ & General_Satisfaction & 0.866 & 0.531 & 0.047 & 11.39 & $* * *$ \\
\hline Job_Involvement & $<---$ & Internal_Work_Motivation & 0.339 & 0.403 & 0.077 & 5.248 & *** \\
\hline $\mathrm{q} 22$ & $<---$ & Communication & 0.649 & 1 & & & \\
\hline $\mathrm{q} 25$ & $<---$ & Communication & 0.596 & 0.858 & 0.042 & 20.36 & $* * *$ \\
\hline q40 & $<---$ & Communication & 0.757 & 1.145 & 0.055 & 20.869 & $* * *$ \\
\hline q27 & $<---$ & Communication & 0.709 & 1.117 & 0.056 & 19.798 & $* * *$ \\
\hline $\mathrm{q} 35$ & $<---$ & Internal_Work_Motivation & 0.453 & 1 & & & \\
\hline $\mathrm{q} 34$ & $<---$ & Internal_Work__Motivation & 0.453 & 0.954 & 0.069 & 13.901 & $* * *$ \\
\hline $\mathrm{q} 33$ & $<---$ & Internal_Work_Motivation & 0.854 & 1.672 & 0.132 & 12.67 & $* * *$ \\
\hline $\mathrm{q} 31$ & $<---$ & Internal_Work_Motivation & 0.773 & 1.958 & 0.165 & 11.836 & $* * *$ \\
\hline $\mathrm{q} 36$ & $<---$ & General_Satisfaction & 0.897 & 1 & & & \\
\hline $\mathrm{q} 4$ & $<---$ & General_Satisfaction & 0.636 & 0.658 & 0.036 & 18.363 & $* * *$ \\
\hline $\mathrm{q} 28$ & $<---$ & General_Satisfaction & 0.741 & 0.834 & 0.04 & 21.012 & $* * *$ \\
\hline q13 & $<---$ & General_Satisfaction & 0.443 & 0.472 & 0.035 & 13.561 & $* * *$ \\
\hline q1 & $<---$ & Job_Involvement & 0.529 & 1 & & & \\
\hline $\mathrm{q} 38$ & $<---$ & Job_Involvement & 0.518 & 0.83 & 0.045 & 18.565 & $* * *$ \\
\hline q19 & $<---$ & Job_Involvement & 0.489 & 0.933 & 0.061 & 15.27 & $* * *$ \\
\hline q37 & $<---$ & Job_Involvement & 0.425 & 0.833 & 0.062 & 13.4 & $* * *$ \\
\hline
\end{tabular}

However, each group feels differently on a relationship between communication and internal work motivation. The manager regards communications are highly related to internal motivation, while professionals do not feel that way. A successful project manager is expected to be a great communicator. As pervious research mentioned [22] [23], this reach also revealed that managers feels communication as the crucial success factor in project management to motivate their project teams. Some research finds that effective communication leads to more successful projects and hence allowing organizations to become high performers [27]. However, those professionals in the project teams may have different expectations. Since project teams are made up by a diverse group of people with different cultural, geographical, organizational, functional, age related, level of educational backgrounds, a standard communication plan may not be effective [27]. Effective communications within a project team present the biggest challenge for a project management.

\section{Acknowledgements}

This work was supported in part by Grant-in-Aid for Scientific Research (C) 15K03607.

\section{REFERENCES}

[1] Archibald, R. D. (2003). Managing High-Technology Programs and Projects, $3^{\text {rd }}$ Edition, Wiley, NY.
[2] Stackenbruck, L. C. (1981), The Implementation of Project Management, Project Management Institute, PA, John Wiley and Sons Ltd. Publishing House New Yok, 2-3.

[3] Cavendish, P. and Martin, M. D. (1982). Negotiating and Contracting for Project Management, Project Management Institute, PA, 14.

[4] Allen, W.E. and Eng, P. (1991). CMC, PMP, Panalta Management Associates Inc., Calgary, Alberta.

[5] Kapur, G. K. (1995). The Seven Deadly Sins of Project Management, PowerPoint presentation: PMI-ISSIG Webinar, Center for Project Management, CA, slide \#23.

[6] Morris, P. W. G., (1998). Key Issues in Project Management, Chapter 1 of Project Management Handbook, Edited by J. K. Pinto, Jossey-Bass, 5.

[7] Royce, W. (1998). Software Project Management: A Unified Framework, Addison-Wesley, Inc., 75.

[8] Cooper, R. G., Edgbert S. J., and Kleinschmidt, E. K. (2001). Portfolio Management for New Products, Cambridge, MA.

[9] Chaos Report, 2015 (2015) https://www.projectsmart.co.uk/white-papers/chaos-report.pd f, retrieved on July 18, 2016.

[10] Fortune, J., White, D., Jugdev, K. and Walker D. (2011). Looking again at current practice in project management, International Journal of Managing Projects in Business, 4(4), 553-72.

[11] O'Reilly, C.A., Caldwell, D.F. and Barnett, W.P. (1989). Work Group Demography, Social Integration, and Turnover, Administrative Science Quarterly, 34, 21-37.

[12] Feldman, D.C. (1981).The Multiple Socialization of Organizational Members, Academy of Management Review, 6, 309-318. 
[13] Hackman J. R. and Oldham, G. R.(1976). Motivation through the Design of Work: Test of a Theory, Organizational Behavior and Human Performance, 16, 250-279.

[14] Lodahl, T.M. and Kejner, M. (1965). The Definition and Measurement of Job Involvement, Journal of Applied Psychology, 49, 24-33.

[15] Tuckman, B. W. (1965). Developmental Sequence in Small Groups, Psychological Bulletin 63, 384-399.

[16] Bettenhausen, K. L. and Murnighan, J. K. (1985). The Emergence of Norms in Competitive Decision-Making Groups, Administrative Science Quarterly, 30, 350-372.

[17] Feldman, D.C. (1976). A Contingency Theory of Socialization, Administrative Science Quarterly, 21, 433-452.

[18] Feldman, D.C. (1984). The Development and Enforcement of Group Norms, Academy of Management Review 9, 47-53.

[19] Wagner, W. G., Pfeffer, J. and O'Reilly III, C. A. (1984). Organizational Demography and Turnover in Top Management Groups, Administrative Science Quarterly, 29, 74-92.

[20] Duncan, R. (1972). Characteristics of Organizational Environment and Perceived Environment Uncertainty, Administrative Science Quarterly, 17, 313 - 327.

[21] Pfeffer, J. (1982). Organizations and Organization Theory. Pittman, 1-23.

[22] Ancona, D. G. and Caldwell, D. F. (1992). Bridging the Boundary: External Activity and Performance in Organizational Teams, Administrative Science Quarterly, 37(4), 634-665.
[23] PMI, (2013). The Essential Role of Communication, Pulse of the Profession, May 2013. http:/www.pmi.org/learning/ thought-leadership/pulse/essential-role-communications, Retrieved on July 13, 2016.

[24] Alexander, M. (2015). 11 Communication Skills of Effective Project Leaders, CIO, Feb 10, 2015. http://www.cio.com/article/2882199/ project-management/11-communication-skills-of-effective-pr oject-leaders.html, Retrieved on July 13, 2016.

[25] Enokida, Y. and Matsuodani, T. (2004). A Development of Team-Building Skills, Journal of the Society of Project Management, 6(2), 9-11.

[26] Bollen, K. A. (1989). A new incremental fit index for general structural equation models, Sociological Methods and Research, 17, 303-316.

[27] Bentler, P.M. (1990). Comparative fit indexes in structural models, Psychological Bulletin; 238-246.

[28] Browne, M.W. and Cudeck, R. (1993). Alternative Ways of Assessing Model Fit, Sociological Methods and Research.21, 230-239.

[29] Foong, M. Y. (2014). Effective Communication: A Challenge to Project Managers, PM times, April 9, 2014, https://www.projecttimes.com/ articles/effective-communication-a-challenge-to-project-man agers.html, Retrieved on July 27, 2016.

[30] Akaike, H. (1974). A New Look at the Statistical Model Identification. IEE Transactions on Automatic Control, 19(6), 716-723.

[31] Tabachnick, B. \& Fidell, L., (2007). Using Multivariate Statistics. 5th ed. New York: Allyn and Bacon. xxv.

[32] Wheaton, B., Muthen, B., Alwin, D. and Summers, G., (1977). Assessing Reliability and Stability in Panel Models. Sociological Methodology, 8(1), 84-136. 